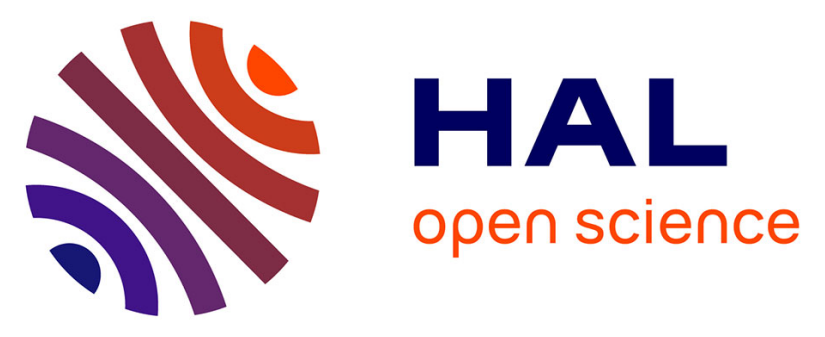

\title{
Photosynthetic response to light and temperature in Laminaria digitata gametophytes from two French populations
}

Gaspard Delebecq, Dominique Davoult, Marie-Andrée Janquin, Luz Valeria Oppliger, Dominique Menu, Jean-Claude Dauvin, François Gevaert

\section{To cite this version:}

Gaspard Delebecq, Dominique Davoult, Marie-Andrée Janquin, Luz Valeria Oppliger, Dominique Menu, et al.. Photosynthetic response to light and temperature in Laminaria digitata gametophytes from two French populations. European Journal of Phycology, 2016, 51 (1), pp.71-82. 10.1080/09670262.2015.1104556 . hal-01231401

\section{HAL Id: hal-01231401 https: / hal.sorbonne-universite.fr/hal-01231401}

Submitted on 25 Nov 2015

HAL is a multi-disciplinary open access archive for the deposit and dissemination of scientific research documents, whether they are published or not. The documents may come from teaching and research institutions in France or abroad, or from public or private research centers.
L'archive ouverte pluridisciplinaire HAL, est destinée au dépôt et à la diffusion de documents scientifiques de niveau recherche, publiés ou non, émanant des établissements d'enseignement et de recherche français ou étrangers, des laboratoires publics ou privés. 


\section{Photosynthetic response to light and temperature in Laminaria digitata}

\section{gametophytes from two French populations}

3 Running head: Stress response in Laminaria digitata gametophytes

4 Gaspard Delebecq • Dominique Davoult • Marie-Andrée Janquin • Luz Valeria

5 Oppliger $\bullet$ Dominique Menu $•$ Jean-Claude Dauvin $•$ François Gevaert

6 G. Delebecq* - M.-A. Janquin - F. Gevaert

7 Université Lille1, Univ Lille Nord de France, Station Marine, 62930 Wimereux, France

8 e-mail: gaspard.delebecq@gmail.com

9 G. Delebecq - D. Menu - M.-A. Janquin - F. Gevaert

10 CNRS, UMR 8187 LOG, 62930 Wimereux, France

11 D. Davoult

12 UPMC Université Paris 06, Station Biologique, 29680 Roscoff, France

13 D. Davoult

14 CNRS, UMR 7144 AD2 M, 29680 Roscoff, France

15 L. V. Oppliger

16 Departamento de Ecología, Facultad de Ciencias Biológicas, Pontificia Universidad

17 Católica de Chile, Post-code 6513677, Santiago, Chile. 
18 J.-C. Dauvin

19 Université de Caen Basse Normandie, 14000 Caen, France

20 J.-C. Dauvin

21 CNRS, UMR 6143 M2C, 14000 Caen, France

$22 *$ present address: Université de Bretagne Occidentale, Institut Universitaire Européen

23 de la Mer, 29280 Plouzané, France and CNRS, UMR 6539 LEMAR, 29280, Plouzané,

24 France 
27 Given the growing body of evidence on the general decline of kelp beds worldwide, it is crucial to understand the physiological response of kelp gametophyte stages to environmental parameters. We investigated the physiological response of gametophytes to light and temperature in two populations of Laminaria digitata occurring in two contrasting environments along the French coast of the English Channel. Results indicate that gametophytes of both populations were highly tolerant to high light through an efficient down-regulation of photosynthesis triggered by the activation of the xanthophyll cycle. Temperature increases promoted photosynthesis and the photosystem II showed high resistance to short-term exposure to high temperatures currently encountered in the field.Gametophytes from the two sites displayed some differences in their pigment contents and photosynthetic characteristics, but low replication size and difference in time of sampling did not permit to confirm a potential local adaptation to the light conditions at each site, as observed in previously published results on adult sporophytes. Gametophytes of L. digitata appeared to be resistant to irradiation and temperature conditions currently experienced in the field, confirming their role in persistence of kelp species under stressful environmental conditions.

Keywords: Phaeophyceae, Photosynthesis, Xanthophyll Cycle, Stress, Phenotypic Plasticity, English Channel 
50 Kelps are major structural components of the cold temperate and boreal coastal communities (Lüning, 1990). They form a highly productive habitat (Mann, 1973) that harbours a rich biodiversity (Christie et al., 2003). The ecological role of kelp is threatened by their expected vulnerability to changes in the physical environment caused by rapid climate change (Wernberg et al., 2011a; Raybaud et al., 2013) or extreme events (Wernberg et al., 2013), especially near range edges, where populations are at the front line of environmental change (Wernberg et al., 2011b).

The persistence of kelp forests mainly depends on the recruitment, growth, competition and the physiological tolerance to environmental factors of the microscopic stages (Reed \& Foster, 1984; Ladah \& Zertruche-Gonzales, 2007; Matson \& Edwards, 2007), which are the crucial phases of the complex heteromorphic life cycle of kelp (Sauvageau, 1915). Gametophytes and embryonic sporophytes can delay their development and reproduction for several months (Carney, 2011) until favourable conditions occur and therefore promote rapid recruitment in the best conditions (Edwards, 2000).

Kelp microscopic stages are subject to environmental conditions that differ from those experienced by the macroscopic sporophytes (Reed \& Foster, 1984; Martinez \& Santelices, 1998) and can therefore have different physiological optima and tolerance levels (Hanelt et al., 1997; Altamirano et al., 2004; Matson \& Edwards, 2007). Even under similar environmental conditions, the response of haploid stages differs from those of diploid stages among various taxa of macroalgae (Roleda et al., 2008; Wang et al., 2011). Hence, in the context of environmental change, enhancing the understanding 
of the physiological tolerance of kelp must incorporate the study of their multiple lifestages, including their microscopic phases (Harley et al., 2012; Wernberg et al., 2012).

Among the potentially adverse environmental conditions, light and temperature can greatly affect the development and survival of microscopic stages and their vulnerability generally determines the ecological success of the species (Bartsch et al., 2008).

Extremely high light has been shown to be adverse for the development and viability of post-settlement stages (gametophytes and embryonic sporophytes) (Lüning \& Neushul, 1978; Fetjek et al., 2011). Likewise, extreme high temperature events (such as El Niño events) have been shown to affect the reproductive success of gametophytes (Ladah \& Zertruche-Gonzales, 2007; Oppliger et al., 2012).

The photosynthetic apparatus is one of the main targets of these abiotic stressors (Walters, 2005). Rapid fluctuation of light and temperature can cause disruptive stresses (Davison \& Pearson, 1996) and affect the survival of kelp gametophytes. Drastic and rapid changes in light exposure and temperature are frequently experienced within a single day (Gevaert et al., 2003; Delebecq et al., 2011) and especially during sunny spring tides.

Therefore, the ability to withstand stressful conditions and to recover from them is crucial for preventing damage to the photosynthetic apparatus and maintaining sufficient photosynthetic performance. After the onset of stressful conditions, the regulation of energy absorption and utilization is essential (Raven \& Geider, 2003). Photoinhibition is the down-regulation of photosynthesis, whose extent is determined by the balance between the rate of photodamage and the rate of repair of photosystem II (PSII) (Takahashi \& Murata, 2008). Photoinhibition has been observed in the field on 
macroscopic sporophyte stages (Gevaert et al., 2003; Delebecq et al., 2011), in the laboratory on zoospores (Roleda, 2009) and in the gametophytic and embryonic sporophyte stages of kelp (Hanelt et al., 1997; Altamirano et al., 2004). Factors other than light, such as temperature, can accelerate photoinhibition by altering the PSII repair mechanisms (Takahashi \& Murata, 2008). Toxic active derivatives of oxygen (oxygen radicals), byproducts of photosynthesis, can also be over-produced under adverse environmental conditions (when exceeding the scavenging potential of cells) and can alter the biological integrity of cells (Ledford \& Niyogi, 2005; Allakverdiev et al., 2008).

To cope with excess light, energy is dissipated in the form of heat to rapidly regulate light harvesting; this mechanism is widespread in photoautotrophs (Raven \& Geider, 2003). Increased thermal energy dissipation of excess light involves the xanthophyll cycle in brown algae, which plays a major role in the fast-dynamic acclimation to change in light, temperature and desiccation in macroscopic sporophytes (FernandezMarin et al., 2011). However, the implication of xanthophyll cycle in the photoprotection process in kelp gametophytes has only been mentioned (Hanelt et al., 1997; Altamirano et al., 2004), without being clearly demonstrated.

Laminaria digitata Hudson Lamouroux (1813), a kelp species of high ecological and economical value, has been shown to be retreating from several sites along the French coasts (Arzel, 1998; Davoult et al., 2011), sparking research to determine the reasons for this decline. Physical stress and environmental changes may contribute to a reduction in the fitness of the gametophytic developmental stages of L. digitata. In this study, we tested the sensitivity of $L$. digitata gametophytes to changing photon flux density and temperature. The investigations were carried out on two populations of $L$. 
digitata along the French coast of the English Channel inhabiting contrasting environmental conditions (Delebecq et al., 2013). The differences in local environmental conditions may result in different sensitivities among the populations that need to be taken into account in understanding the effect of environmental factors on organisms. In this study, we also measured the role of the xanthophyll cycle in the non-photochemical quenching in gametophytes of $L$. digitata in response to excess light.

\section{Materials and Methods}

Study site

A complete description of the two sites and environmental conditions during experiments is given in Delebecq et al., (2013); consequently, we describe only the main characteristics of both sites here. We collected the seaweed material from two populations of L. digitata, growing in the upper subtidal zone $(0-1 \mathrm{~m})$ of a rocky shore in Roscoff $\left(48^{\circ} 5^{\prime} \mathrm{N}, 3^{\circ} 6^{\prime} \mathrm{W}\right)$ and in Wissant $\left(50^{\circ} 5^{\prime} \mathrm{N}, 1^{\circ} 4^{\prime} \mathrm{E}\right)$, located in the western and eastern part of the English Channel, respectively. The sites were selected for their large kelp stands and also for their contrasting environmental conditions. Light attenuation $\left(\mathrm{m}^{-1}\right)$ of photosynthetically active radiation $(400-700 \mathrm{~nm})$ ranged from 0.09 to $0.57 \mathrm{~m}^{-}$ ${ }^{1}$ in Roscoff and from 0.19 to $0.96 \mathrm{~m}^{-1}$ in Wissant (Delebecq et al., 2013) due to high turbidity in the eastern English Channel. Seawater surface temperature displays high seasonal variation at both sites, with a slightly broader annual temperature range in Wissant, from $5^{\circ} \mathrm{C}$ in winter to $20^{\circ} \mathrm{C}$ in summer, than in Roscoff, from $8^{\circ} \mathrm{C}$ in winter to $17^{\circ} \mathrm{C}$ in summer, due to the influence of the North Atlantic Ocean and depth of the 
continental shelf. Environmental conditions in the two sites at the time of collection and

1431 month prior to sampling are given in Table 1.

Sampling and culture conditions

145 Fertile sporophytes of L. digitata were collected at low tide in November 2008 in

146 Roscoff, and in February 2009 in Wissant. L. digitata is reproductive most of the year in

147 Roscoff, but the main spore/gamete release events generally occur in August-September and November-December in Northern Brittany (Arzel, 1998). In Wissant, L. digitata is reproductive at the end of winter and throughout spring. Mature sori were cut, cleaned, and dried at $10^{\circ} \mathrm{C}$ and in the dark for several hours. Sori were subsequently washed with distilled water and sterile seawater, and placed in $50 \mathrm{~mL}$ Falcon tubes (BD Biosciences, San Jose, CA, USA), filled with sterile Provasoli enriched seawater (PES) (Provasoli, 1968), and maintained overnight in the dark on a rotary shaking table to induce zoospore release. Zoospores in suspension were checked with inverted-light microscope to ensure that zoospores were viable, before being placed in Petri dishes (BD Falcon, Franklin Lakes, NJ, USA). Zoospores were allowed to settle and developing gametophytes were cultured in thermostatic chamber at $10^{\circ} \mathrm{C}$ under an irradiance of 35 $\mu$ mol photons $\mathrm{m}^{-2} \mathrm{~s}^{-1}$ (photon flux density, PFD, 400-700 nm), produced by fluorescent tubes (L8W/840, cool white, Osram, Germany) in a light:dark cycle 12:12 h. PFD was measured with a cosine-corrected quantum sensor (Li-192SA, LiCor, Lincoln, Nebraska, USA), connected to a data logger (Li 1400, LiCor, Lincoln, Nebraska, USA). The medium was changed once a week. Experiments started approximately after 1 month of cultivation when the density was high enough for fluorescence measurements.

164 The density of the gametophytes was $4711 \pm 1140$ ind $\mathrm{m}^{-2}$ for Roscoff ( $43 \pm 3 \%$ cover) and $3600 \pm 691$ ind $\mathrm{m}^{-2}$ for Wissant $(41 \pm 7 \%$ cover $)$. Gametophytes were composed of 
166 few cells and arranged as homogenous thick layers at the bottom of the Petri dishes.

167 Gametophytes were isolated from three different parents at each site $(n=3)$ and were

168 cultivated separately to ensure independent replicates.

169

170

171

172

173

\section{Oxygen production}

Dark respiration $\left(\mathrm{R}_{\mathrm{d}}\right)$ and net oxygen production $(\mathrm{NP})$ was measured polarographically at culture temperature $\left(10^{\circ} \mathrm{C}\right)$, using a water-jacket thermostatic DW2/2 chamber combined with a "Clark-type" oxygen electrode and a computer-interfaced box CB1 (Hansatech Instruments, Kings Lynn, Norfolk, UK). The gametophytes were first detached from the substrate and resuspended several days prior to the experiment. Detaching gametophytes from their substrate does not affect their growth, their photosynthetic performance or their respiration (Fain \& Murray, 1982). The gametophytes were held $12 \mathrm{~h}$ in the dark prior to the experiment, and then placed in the measurement chamber filled with $2 \mathrm{~mL}$ of PES and mixed with a magnetic stirrer. To prevent oxygen saturation, a quarter of the medium was renewed after each light step. To do so, a silk filtering mesh was used to retain the gametophytes in the media. Respiration was measured in the dark, and gametophytes then underwent lightincreasing steps of 20 min each (13 light steps, ranging from 2.5 to $500 \mu$ mol photons $\mathrm{m}^{-2} \mathrm{~s}^{-1}$ ) using a halogen lamp (KL 2500 LCD, Schott, Germany) with a daylight cut-off filter (Schott, Germany). $\mathrm{R}_{\mathrm{d}}$, NP and gross oxygen production (GP) rates were calculated based on fresh weight $\left(\mathrm{FW}, \mu \mathrm{mol} \mathrm{O} \mathrm{g}_{\mathrm{FW}}{ }^{-1} \mathrm{~h}^{-1}\right)$ and chlorophyll $a$ content $(\mathrm{chl}$ $a, \mu$ mol $\mathrm{O}_{2}$ nmoles chl $a^{-1} \mathrm{~h}^{-1}$,). FW was measured after collecting gametophytes on a silk filtering mesh that had previously been weighed.

\section{Fluorescence}


In vivo chl $a$ fluorescence of the photosystem II (PSII) of gametophytes was measured using an underwater fluorometer (diving PAM; Heinz Walz, Effeltrich, Germany). The optimal quantum yield $\left(F_{v} / F_{m}\right)$ of PSII (Genty et al., 1989), a measure of the maximum efficiency of PSII, was measured using a $0.8 \mathrm{~s}$ saturating pulse $\left(2500 \mu \mathrm{mol}\right.$ photons $\mathrm{m}^{-2}$ $\mathrm{s}^{-1}$ ) of white light. We calculated the relative $F_{v} / F_{m}$ ratio $\left(\right.$ rel. $\left.F_{v} / F_{m}\right)$ by dividing all data by the initial value measured at the beginning of the experiment in the dark.

The effective quantum yield of PSII $\left(\phi_{P S I}\right)$, the efficiency of PSII photochemistry, was measured using a custom-made clip for Petri dishes to ensure a constant distance of 5 $\mathrm{mm}$ between the probe and the sample. The $\phi_{P S I I}$ was calculated according to Genty et al. (1989) and used to estimate the linear electron transport rate (relative electron transport rate, rETR) (Gevaert et al., 2003), an estimator of photosynthesis.

Non-photochemical quenching $(N P Q)$ indicates thermal dissipation of excess light in the PSII antennae, a photoprotective mechanism. We assumed that a stable $N P Q$ level is reached after a 10-min illumination period, as shown in several microalgal species (Casper-Lindley \& Björkman, 1998). $F_{m}$ ' values measured under very weak irradiance were higher than $F_{m}$ values measured after dark-adaptation; therefore $N P Q$ values were computed using the higher $F_{m}$ ' value instead of $F_{m}$ (Serodio et al., 2005).

rETR and NPQ were measured on gametophytes at the end of each light-increasing step of 10 min each (12 light steps, ranging from 2.5 to $250 \mu \mathrm{mol}$ photons $\mathrm{m}^{-2} \mathrm{~s}^{-1}$ ). The $N P Q$ value measured under the maximal irradiance is referred to as $N P Q_{250}$.

\section{P-I curves, rETR-I}

The light-saturated maximum rate of GP $\left(P_{\max }\right)$, the light-saturated maximum rate of relative electron transfer $\left(r E T R_{\max }\right)$, the light-limited initial slope $(\alpha)$, and the saturation 
onset irradiance level $\left(I_{k}\right)$ were calculated by plotting computed oxygen production rates and $r E T R$ against irradiance. $P_{\max }$ represents the maximal oxygen production, including all photosynthetic processes, while $r E T R_{\max }$ is an estimation of the linear electron transfer in PSII, an indication of the overall photosynthetic capacity. Data were fitted using the model of Eilers \& Peeters (1988) to each replicate with a least-square regression, using the Simplex method in the Statistica computer package (Statsoft, Tulsa, OK, USA).

\section{Response to high irradiance}

To study high light stress, the settled gametophytes in a Petri dish filled with PES at cultivation temperature were exposed to $500 \mu \mathrm{mol}$ photons $\mathrm{m}^{-2} \mathrm{~s}^{-1}$ for $2 \mathrm{~h}$, and then, to dim light $\left(10 \mu \mathrm{mol}\right.$ photons $\left.\mathrm{m}^{-2} \mathrm{~s}^{-1}\right)$ to allow recovery. $F_{v} / F_{m}, \phi_{P S I I}, r E T R$ and $N P Q$ were measured every $30 \mathrm{~min}$. Samples for pigment analyses were simultaneously collected at the start of the experiment, at the end of the light stress, and $2 \mathrm{~h}$ after the return to dim light. Gametophytes were detached from the substrate and the gametophyte suspension was filtered on a $20 \mu \mathrm{m}$ silk filtering mesh and subsequently deep-frozen in liquid nitrogen for further pigment analyses.

First, rETR-I curves were constructed for gametophytes acclimated $4 \mathrm{~h}$ at four different temperatures $\left(5^{\circ} \mathrm{C}, 10^{\circ} \mathrm{C}, 15^{\circ} \mathrm{C}\right.$ and $\left.20^{\circ} \mathrm{C}\right)$ controlled by a thermo fluid circulator bath. During acclimation, $F_{\vee} / F_{m}$ was measured hourly. Then, gametophytes underwent a progressive increase and decrease temperatures $\left(2^{\circ} \mathrm{C}\right.$ every $\left.15 \mathrm{~min}\right)$ with an initial temperature set at $10^{\circ} \mathrm{C} . F_{\downarrow} / F_{m}$ was measured at the end of each temperature step. 
235 Pigment contents of gametophytes were extracted by sonication and grinding in a cold mortar with methanol and methylene chloride. Extracts were centrifuged and supernatants were collected and dry-evaporated under nitrogen. Salt contents of the extracts were removed and the organic phase was evaporated and dissolved in methanol

239 for injection. Pigment analysis was performed by high performance liquid chromatography (HPLC) (Beckman, system Gold, 126) with a reverse-phase column (C 18 Allure, Restek). Separation was performed with a solvent delivery profile adapted from Arsalane et al., (1994). Pigment contents were quantified using specific absorption coefficients and normalised to the total pigment content. The conversion of violaxanthin into antheraxanthin and zeaxanthin was estimated by calculating the de-epoxidation ratio (DR):

$\mathrm{DR}=($ antheraxanthin + zeaxanthin $) /($ violaxanthin + antheraxanthin + zeaxanthin $)$ $c$ pigment concentrations normalised to $\operatorname{chl} a$ (moles per $100 \mathrm{~mol}$ of $\operatorname{chl} a$ ) were pooled, and referred to as the antenna pigment pool. Violaxanthin, antheraxanthin and zeaxanthin concentrations normalised to chl $a$ were pooled, referred to as the xanthophyll cycle pool.

\section{Statistical analyses}

Student's $t$-test $(t)$ (with Welch correction) was used to test for the difference between means of the photosynthetic parameters $\left(P_{\max }, r E T R_{\max }, \alpha\right.$ et $\left.I_{k}\right)$, the $F_{\downarrow} / F_{m}, N P Q$ values and pigment contents after the dataset was tested for normality using the Shapiro-Wilk test (Shapiro \& Wilk, 1965). Response to light or temperature was fitted and response 
within sites using a $t$-test for paired samples $\left(\mathrm{t}_{(\mathrm{p})}\right)$ after checking the data for normality.

259

260

261

262

263

264

265

266

267

268

269

270

271

272

273

274

275
Adjustment of $P$ values for multiple testing was done using the Holm method. The effect of temperature on the response parameters of light-response curves was analysed using a PERMANOVA (Anderson, 2001) in the vegan package of R software. Post hoc power analysis $(1-\beta)$ were performed on non significant results using $\mathrm{G}^{*}$ Power software which automatically determine the effect size (Faul et al., 2007). All experimental units had three replicates $(n=3)$.

\section{Results}

Comparison of the photosynthetic activity between the two sites

Gametophytes from the two sites showed differences in their photosynthetic parameters (Fig. 1). When normalized to chl $a, P_{\max (\operatorname{chl} l a)}$ values, the light-saturated maximal gross oxygen production values, were higher in Roscoff than in Wissant $(t=8.0$, Holmadjusted $P=0.003$ ), with $0.27 \pm 0.01 \mu \mathrm{mol} \mathrm{O}$. nmoles chl $a^{-1} \mathrm{~h}^{-1}$ in Wissant, and $0.95 \pm$ $0.15 \mu \mathrm{mol} \mathrm{O} \mathrm{O}_{2}$ nmoles chl $a^{-1} \mathrm{~h}^{-1}$ in Roscoff (Fig. 1 C). $r E T R_{\max }$ values $(22.74 \pm 5.37$ $\mu \mathrm{mol} \mathrm{e} \mathrm{m}^{-2} \mathrm{~s}^{-1}$ in Wissant and $15.90 \pm 0.77 \mu \mathrm{mol} \mathrm{e}^{-} \mathrm{m}^{-2} \mathrm{~s}^{-1}$ in Roscoff), the lightsaturated maximal electron transfer rates, and $P_{\max (F W)}$ on a FW basis $(56.47 \pm 13.18$ $\mu \mathrm{mol} \mathrm{O} \mathrm{g}_{\mathrm{FW}}{ }^{-1} \mathrm{~h}^{-1}$ in Wissant and $38.33 \pm 1.12 \mu \mathrm{mol} \mathrm{O} \mathrm{g}_{\mathrm{FW}}{ }^{-1} \mathrm{~h}^{-1}$ in Roscoff), were not significantly different between two sites $\left(t=2.9\right.$, Holm-adjusted $P=0.133$ for $r E T R_{\max }$; $t=2.8$, Holm-adjusted $P=0.142$ for $P_{\max (F W)}$ values) $($ Fig. 1 A-B $)$, likely due to low statistical power resulting from small sample sizes $\left(0.39\right.$ for $r E T R_{\max }$ and 0.32 for $P_{\max (F W)}$. 
280

281

282

283

284

285

286

287

288

289

290

291

292

293

294

295

296

297

298

299

300

301

The same pattern appeared for the ascending slope under light limitation ( $\alpha$ values).

$\alpha_{(\text {chla })}$ values were significantly higher in Roscoff than in Wissant (respectively $0.005 \pm$ 0.001 in Wissant and $0.023 \pm 0.002$ in Roscoff $)(t=13.9$, Holm-adjusted $P=0.001)$ when expressed on a chl $a$ basis, whereas no differences were observed when expressed in electron transport rates or when expressed on a FW basis (respectively $0.37 \pm 0.06$ in Wissant and $0.40 \pm 0.03$ in Roscoff; $t=0.68$, Holm-adjusted $P=0.534$ for $\alpha_{(r E T R)}$ and $1.15 \pm 0.17$ in Wissant and $0.99 \pm 0.09$ in Roscoff $t=1.39$, Holm-adjusted $P=0.305$ for $\left.\alpha_{(\mathrm{FW})}\right)$ which can also result from very low statistical power (respectively 0.09 and 0.19 ).

Considering the light saturation parameter $\left(I_{k}\right)$, no significant differences were found between the two sites but the low statistical powers suggest that there were not enough replication to resolve the differences $(t=1.95$, Holm-adjusted $P=0.245$ and $1-\beta=0.30$ for $I k_{(r E T R)}, t=1.77$, Holm-adjusted $P=0.152$ and $l-\beta=0.28$ for $I k_{(F W)}$ and $t=1.13$, Holm-adjusted $P=0.322$ and $1-\beta=0.14$ for $\left.I k_{(\text {chla })}\right)$. Despite this lack of significant differences, average $I k$ values in gametophytes from Wissant were always greater than $I k$ values in gametophytes from Roscoff $\left(62.67 \pm 20.20 \mu \mathrm{mol}\right.$ photons $\mathrm{m}^{-2} \mathrm{~s}^{-1}$ in Wissant, and $39.71 \pm 1.73 \mu \mathrm{mol}$ photons $\mathrm{m}^{-2} \mathrm{~s}^{-1}$ in Roscoff on an electron rate basis; $49.44 \pm 9.83 \mu \mathrm{mol}$ photons $\mathrm{m}^{-2} \mathrm{~s}^{-1}$ in Wissant, and $38.83 \pm 3.42 \mu \mathrm{mol}$ photons $\mathrm{m}^{-2} \mathrm{~s}^{-1}$ in Roscoff on a FW basis and 52.39 \pm 13.49 in Wissant and $41.98 \pm 8.56$ in Roscoff on a chl $a$ basis).

Despite high irradiance $\left(500 \mu \mathrm{mol}\right.$ photons $\left.\mathrm{m}^{-2} \mathrm{~s}^{-1}\right)$ in comparison with the culture conditions, there was no decrease in oxygen production observed.

\section{Comparison of pigment contents}


Pigment contents were similar at both sites (Table 2) except for chl $c$ and violaxanthin contents, which were higher in Wissant than in Roscoff $(t=4.69$, Holm-adjusted $P=$ 0.047 for chl $c$ and $t=4.26$, Holm-adjusted $P=0.047$ for violaxanthin). When expressed on a total pigment content basis, no differences were observed in chl $a$ contents in both sites, but chl $a$ contents were slightly lower in Wissant and statistical power was low (0.33). Therefore higher $\Sigma \mathrm{XC}$ :chl $a$ pigment ratio may have been expected in Wissant, but the lack of significant difference is believed to be the result of a low statistical power (0.53).

When chl $a$ contents were expressed per unit fresh weight (respectively $47.74 \pm 6.63$ significantly higher in Wissant $(t=4.83$, Holm-adjusted $P=0.036)$.

\section{Comparison of photoprotective capacities}

$N P Q$ was measured along with $r E T R$ (Fig. 2). $N P Q$ values after prolonged darkness (12

$\mathrm{h}$, corresponding to the end of the dark period of culture conditions) were higher than those under weak irradiances. Maximal $F_{m}$ ' values were reached under an average irradiance of $20 \mu \mathrm{mol}$ photons $\mathrm{m}^{-2} \mathrm{~s}^{-1}$ in Roscoff, and $50 \mu \mathrm{mol}$ photons $\mathrm{m}^{-2} \mathrm{~s}^{-1}$ in

318 Wissant.

$N P Q$ progressively developed with increasing irradiance. Maximal $N P Q$ values $\left(N P Q_{250}\right)$ were reached at the highest applied irradiance $\left(250 \mu \mathrm{mol}\right.$ photons $\left.\mathrm{m}^{-2} \mathrm{~s}^{-1}\right)$ and these values were significantly higher in gametophytes from Roscoff than in gametophytes from Wissant $(t=3.5$, Holm-adjusted $P=0.047)$, with $N P Q_{250}$ values of $3.80 \pm 0.42$ in Roscoff and of $2.37 \pm 0.56$ in Wissant 
Intrinsic efficiency of PSII was altered in both populations, as indicated by the strong decline of rel. $F_{\downarrow} / F_{m}$ values (Fig. $3 \mathrm{~A}$ ) when gametophytes were exposed to $500 \mu \mathrm{mol}$ photons $\mathrm{m}^{-2} \mathrm{~s}^{-1}$ for $2 \mathrm{~h}$. It reached a constant level, decreasing by $70 \%$ of the initial $F_{\sqrt{ }} / F_{m}$ value after $2 \mathrm{~h}$ in both populations. In dim light, $F_{\downarrow} / F_{m}$ recovered at a level within $5 \%$ of the initial $F_{\sqrt{ }} / F_{m}$ value after $1.5 \mathrm{~h}$ in Roscoff and after $4 \mathrm{~h}$ in Wissant.

During light stress, there was an increase in DR in gametophytes from Roscoff and from Wissant, corresponding to the progressive de-epoxidation of violaxanthin into antheraxanthin and zeaxanthin $\left(\mathrm{t}_{\mathrm{p})}=7.9\right.$, Holm-adjusted $P=0.025$ for gametophytes from Wissant and $t_{(\mathrm{p})}=8.9$, Holm-adjusted $P=0.025$ for gametophytes from Roscoff)

(Fig. 3 B). The increase in intrinsic efficiency of PSII under dim light was accompanied by a decrease in the DR values in gametophytes from Roscoff $\left(\mathrm{t}_{(\mathrm{p})}=11.6\right.$, Holmadjusted $P=0.022$ ), indicating the reconversion of zeaxanthin and antheraxanthin into violaxanthin. In spite of the difference in the absolute values of DR measured at both sites after $2 \mathrm{~h}$ of strong illumination, the percent increase in DR was similar at both sites with an increase of $160 \%$ of the initial DR values. There was no significant decrease in DR values in Wissant after $2 \mathrm{~h}$ under dim light.

Increasing the temperature resulted in a decrease in $\alpha$ values in Wissant (Fig. 4 A), and an increase in rETR max $_{\text {ax }}$ and $I_{k}$ values for both sites (respectively Fig. 4 B and 4 C) (Table 3). $N P Q_{250}$ was calculated at the end of each $r E T R-E$ curves (Fig. 4 D). When exposed to $20^{\circ} \mathrm{C}$, there was a slight decrease in the $N P Q_{250}$ values, in comparison with the values reached at $10^{\circ} \mathrm{C}$. 
347 The sensitivity of $F_{\downarrow} / F_{m}$ to temperature was tested on a broad range of temperature (Fig.

348 5). At $10^{\circ} \mathrm{C}, F_{v} / F_{m}$ values in the dark were $0.52 \pm 0.09$ in Roscoff and $0.53 \pm 0.06$ in

349 Wissant. With the progressive increase in temperature (from $10^{\circ} \mathrm{C}$ to $32^{\circ} \mathrm{C}$ ), the rel.

$350 \quad F_{v} / F_{m}$ declined for temperatures greater than $20^{\circ} \mathrm{C}$. There were no differences between

351 sites in the response parameters from the regression analysis.

\section{Discussion}

Microscopic stages are thought to be the hardiest life-cycle stages of kelp (tom Dieck 1993). They form a seed bank which persists through stressful environmental conditions and ensures the persistence of species when unfavourable conditions occur, as it may happen during unusual heat waves (Ladah \& Zertuche-Gonzales, 2007, Bartsch et al., 2013). Therefore, a great tolerance of L. digitata gametophytes to stressful environmental conditions is essential. In this study, we tested their physiological tolerance to irradiation and temperature stress in two populations with different environmental conditions along the French coast. The main result of the present study is that gametophytes of L. digitata were highly resistant to the irradiation and temperature treatments that might be locally encountered in the field. It is reinforced by the fact that sori were sampled during months when irradiation and temperature stress are not prevalent: their temperature and irradiation resistance may be even higher during summer.

We set out to study the incidence of high light stress on the photosynthesis of L. digitata gametophytes. Our results demonstrate that gametophytes can cope with prolonged high 
irradiance stress, confirming the great potential for high light tolerance in kelp gametophytes (Iizumi \& Sakanishi, 1994; Hanelt et al., 1997; Altamirano et al., 2004).

This tolerance arises from the efficient thermal dissipation of excess light $(N P Q)$ and, mainly, through the formation of antheraxanthin and zeaxanthin, which induce the conformational change in the light harvesting complexes (LHC) II (Jahns \& Holzwarth, 2009). This zeaxanthin-dependent quenching is a slow component of $N P Q$, and GarciaMendoza \& Colombo-Pallota (2007) have shown that kelp may lack the fast energy or pH-dependent quenching. However, the large xanthophyll cycle pigment pool may accelerate $N P Q$ development and thus compensate for this lack. Under dim light, epoxidation of zeaxanthin and antheraxanthin was virtually complete in less than $1 \mathrm{~h}$. The slowly relaxing component of photoinhibition generally corresponds to the progressive re-activation of PSII or possibly to a conformational change of the LHC, and probably the aggregation if LHC due to zeaxanthin binding (Garcia-Mendoza \& Colombo-Pallotta, 2007). Therefore, our study confirms that this efficient reversible conversion between violaxanthin, antheraxanthin and zeaxanthin in gametophytes (previously suggested by Hanelt et al., 1997 and Altamirano et al., 2004) is a widespread mechanism of fast-dynamic acclimation to abiotic stress in macroalgae (Fernandez-Marin et al., 2011).

Another possible mechanism protecting L. digitata gametophytes from rapid light fluctuations is the maintenance of $N P Q$ in the dark, a mechanism previously observed in microphytobenthos (Serôdio et al., 2005) and in several phytoplankton species (CasperLindley \& Björkman, 1998; Cruz et al., 2011). In Pelvetia canaliculata, the NPQ of chl $a$ fluorescence in the dark depends on the activation of violaxanthin de-epoxidase (Fernandez-Marin et al., 2011), which is triggered by acidification of the lumen due to 
metabolic activity in the dark (Cruz et al., 2011). This activation may thus sustain ATP synthase activity (Casper-Lindley \& Björkman, 1998; Serôdio et al., 2005), and prevent the formation of oxygen radicals. $N P Q$ in the dark may therefore represent a type of sustained photoprotection, maintaining a dissipative state through pre-formed zeaxanthin or antheraxanthin, as observed here.

Acclimation to higher irradiances than the culture irradiance used in this experiment and/or an intermittent light exposure may have also provided a higher tolerance to the two- hour light stress of $500 \mu \mathrm{mol}$ photons $\mathrm{m}^{-2} \mathrm{~s}^{-1}$ (Han and Kain, 1996; Lavaud et al., 2002). Along the French coast of the English Channel, irradiance of $500 \mu$ mol photons $\mathrm{m}^{-2} \mathrm{~s}^{-1}$ and more can be recorded during spring and summer low spring tides (Gevaert et al., 2003; Delebecq et al., 2011; Delebecq et al., 2013), but actual incident irradiances are generally deeply attenuated by the sporophyte canopy (Gerard, 1984) which may hypothesized that gametophytes display a great tolerance to high light.

This study also highlighted that the photosynthetic performance of L. digitata gametophytes were not negatively affected by short-term fluctuations in water temperature as it may be locally encountered in the field during periods of low tide. Gametophyte PSII - essential for the whole photochemistry process (Havaux \& Tardy, 1996; Roleda, 2009) — shows high resistance to the temperatures currently encountered in the field. Increased temperature promotes electron transfer via the PSII through an increase in thylakoid membrane fluidity (Havaux \& Tardy 1996) and results in an increase in maximum relative electron transfer rates $\left(r E T R_{\max }\right)$ and in the onset of saturation parameters $\left(I_{k}\right)$, as observed here. An increase in gross oxygen production with temperature can therefore be expected up to an optimum (Sukenik et al., 1987), 
417 since the relationship electron transport rate and gross oxygen production is robust,

418 provided that the temperature changes are not extremes (Morris \& Kromkamp, 2003).

419 Above an optimal temperature (above $20^{\circ} \mathrm{C}$ in this study), a complex set of inactivation 420 and denaturation occur in thylakoïd, accompanied by the generation of elevated levels

421 of reactive oxygen species which reduces photosynthetic capacity (Sharkey, 2005;

422 Allakhverdiev et al., 2008) and also the ability to cope with high light stress (Roleda, 423 2009). Superoptimal temperature also promotes electron-consuming processes (such as 424 cyclic electron transfer) and dark respiration (Fain \& Murray, 1982; Sharkey, 2005; 425 Henkel \& Hofmann, 2008) which can result in negative net photosynthesis.

426 However, short-term temperature responses do not provide insight into long-term 427 individual survival with regard to temperature: temperature optima for photosynthesis 428 can be several degrees higher than temperature optima for survival and growth (Davison, 1991) as it is not possible to evaluate the extent of sublethal stress.

430 Concerning L. digitata gametophytes, tom Diek (1993) showed that they were able to 431 survive 8 weeks at $23^{\circ} \mathrm{C}$, demonstrating that gametophytes are moderately resistant to 432 temperature extremes that are rarely encountered across its geographic range. Moreover, there is seasonal acclimation of the temperature response of gametophytes (Lee \& Brinkhuis, 1988) and temperature resistance of PSII may be even higher in gametophytes sampled in warmer months or acclimated to higher temperatures

436 (Mohring et al., 2013).

The two sites from which gametophytes were obtained were known to display different seasonal range of abiotic conditions (Berx \& Hughes, 2009; Delebecq et al 2013), and a 
strong photoacclimation to local environmental conditions of sporophytes of L. digitata

441 from the two same sites was previously highlighted (Delebecq et al., 2013).Here, we

442 found some differences in the physiological characteristics of gametophytes between the

443 two sites, however the small replication did not exhibit the full physiological diversity

444 of the populations investigated, and replication was clearly not sufficient to resolve the

445 differences as indicated by the very low statistical power of our analysis (never

446 exceeding 53\%). Moreover, results in the present study are confounded by the different

447 environmental conditions at the time of sampling in the two sites (Table 1) that may

448 influence the physiological response of gametophyte even after one month cultivation

449 under lab conditions, depending on the time-scale of acclimation to new light and

450 temperature treatments. More information on seasonal changes that can occur in the

451 gametophytes from Roscoff and Wissant would be necessary for a more complete

452 picture of the gametophyte response in the English Channel taking into account the

453 variation of the whole set of past and present environmental conditions, and to test if the

454 photosynthetic characteristics measured in sporophytes may be conserved in

455 gametophytes.

456 The higher chl $a$ concentrations and fucoxanthin contents in gametophytes from

457 Wissant may suggest a greater light-harvesting efficiency and a higher density of

458 reaction centres (Gerard, 1988), which generally result in higher photosynthetic rates.

459 Although maximal photosynthetic rates $\left(r E T R_{\max }\right.$ and $\left.P_{\max W W}\right)$ in Wissant were not

460 significantly different from those in Roscoff, it is believed to result of low statistical

461 power, as indicated by the differences observed in $P_{\text {maxchla }}$. Hence, $P_{\text {maxchla }}$ was higher in

462 Roscoff than in Wissant, indicating less efficient light use per chl $a$ molecule in the

463 gametophytes from Wissant. This difference may be due to the self-shading of the LHC, 
i.e. the fact that light absorption do not increase despite a higher pigment concentration

465 (Falkowski \& Raven, 1997). Daily underwater irradiances were shown to be similar in

both sites at the time of sampling (Delebecq et al., 2013). As thermal acclimation is

known to induce change in photoacclimation status (Machalek et al., 1996), those differences in photosynthetic characteristics may be partly due to the lower sea surface temperature in Wissant at the time of sampling (Table 1), if initial temperature encountered in the field still influence gametophyte's response to light, even after one month cultivation.

Then, the larger violaxanthin content in Wissant may compensate for the large antenna size (higher fucoxanthin contents) which is known to decrease the probability of encounters between violaxanthin and violaxanthin de-epoxidase and the speed of deepoxidation under high light (Garcia-Mendoza \& Colomba-Palotta, 2007). It may also be due to the faster changing light conditions imposed by higher light attenuation in Wissant. Violaxanthin is also involved in the response to other abiotic stressors (Havaux \& Tardy, 1996; Fernandez-Marin et al., 2011). Thus, a larger pool of violaxanthin may help gametophytes from Wissant to cope with other abiotic stressors not tested in this study.

We found no differences in the temperature response of the two sites with respect to the resistance of PSII quantum efficiency and increasing temperature. We expected that the wider temperature range encountered in Wissant may have induced a difference in thermostability of PSII. The small difference in temperature range may have not been sufficient to produce detectable differences. Moreover, at the time of sampling, 
temperature was lower in Wissant $\left(5^{\circ} \mathrm{C}\right)$ than in Roscoff $\left(12^{\circ} \mathrm{C}\right)$ and this difference may have influenced the photosynthetic response of gametophytes in our study (Lee \& Brinkhuis, 1988; Mohring et al., 2013). Beside thermal conditions and sampling time, the low replication size of our experiments may have been not sufficient to draw a well supported conclusion on the lack of difference between the two sites.

492 Regarding the temperature response of gametophytes, Bolton \& Lüning (1982) suggested that Laminaria species may show sufficient phenotypic plasticity to adjust to the temperature range along its distribution and is not composed of differentiated temperature-adapted ecotypes throughout its range. However, notwithstanding similar growth patterns, physiological differences in the response to temperature may nevertheless occur among populations of perennial brown seaweeds (Henkel \& Hofmann, 2008; Staehr \& Wernberg, 2009). In order to test for difference in temperature response of the L. digitata's populations along the French coast, further experiments need to compare gametophytes from (1) the two sites at different times of the year during their respective sporulation periods (Mohring et al., 2013) and (2) sites experiment (Fredersdorf et al., 2009).

Gametophytes appeared to be resistant to the light and temperature conditions currently experienced in the field. Regarding vulnerability to environmental conditions, physiological studies on the interactive effects of multiple abiotic stressors are required to improve our understanding of the microscopic stages in kelp (Fredersdorf et al., 2009). For instance, desiccation tolerance (Contreras-Porcia et al., 2012), ultraviolet 
radiation (Roleda et al., 2006) and burial in sediment deposition (Roleda et al., 2011) all

511 affect microscopic stages. While the southern geographic range-limit of L. digitata is

512 thought to be set by inhibition of reproduction, as it was observed by Bartsch et al.

513 (2013) when temperature reaches $18^{\circ} \mathrm{C}$, survival of microscopic stages remains essential

514 to cope with unusual stressful conditions. There is also an important need to obtain

515 more information on the persistence of these stages in the field. It could help in defining

516 which environmental conditions are really encountered in the field by the different

517 microscopic developmental stages. Despite the present study failed to report local

518 variation in the physiological response of L. digitata, it remains essential to take into

519 account local variation in predicting the impact of fast-changing conditions in coastal 520 areas.

\section{Acknowledgments}

524 We would like to thank the BEDIM Team of the Station Biologique de Roscoff and especially M. Valero and C. Destombe for their valuable support and also for receiving, and providing seaweed material. We also thank the Service Mer et Observation at the

527 Station Biologique de Roscoff and A. Migné for their valuable support during field sampling. We greatly thank Marie Cachera for her help in statistical analyses. This study was funded by the Agence Nationale de la Recherche (ANR ECOKELP). We thank the three reviewers for their remarks and advice that helped to improve the manuscript. 


\section{References}

534 Allakhverdiev, S.I., Kreslavski, V.D., Klimov, V.V., Los, D.A., Carpentier, R., Mohanty, P. (2008). Heat stress: an overview of molecular responses in photosynthesis. Photosynthesis Research, 98: 541-550.

Altamirano, M., Murakami, A., Kawai, H. (2004). High light stress in the Kelp Ecklonia cava. Aquatic Botany, 79: 125-135.

Anderson (2001). A new method for non-parametric multivariate analysis of variance. Austral Ecology, 26: 32-46.

Bartsch, I., Vogt, J., Pehlke, C., Hanlet, D. (2013). Prevailing surface temperature inhibit summer reproduction of the kelp Laminaria digitata at Helgoland (North Sea). Journal of Phycology, 49: 1061-1073. 
Berx, B., Hughes, S.L. (2009). Climatology of surface and near-bed temperature and salinity on the North-West European continental shelf for 1971-2000. Continental Shelf Research, 29: 2286-2292.

Carney, L.T. (2011). A multispecies laboratory assessment of rapid sporophyte recruitment from delayed kelp gametophytes. Journal of Phycology, 47: 244251.

Bolton, J.J., Lüning, K. (1982). Optimal growth and maximal survival temperatures of Atlantic Laminaria species (Phaeophyta) in culture. Marine Biology, 66: 89-94.

Casper-Lindley, C., Björkman, O. (1998). Fluorescence quenching in four unicellular algae with different light-harvesting and xanthophyll-cycle pigments. Photosynthesis Research, 56: 277-289.

Christie, H., Jorgensen, N.M., Norderhaug, K.M., Waage-Nielsen, E., (2003). Species distribution and habitat exploitation of fauna associated with kelp (Laminaria hyperborea) along the Norwegian Coast. Journal of the Marine Biological Association of the United Kingdom 83: 687-699.

Contreras-Porcia, L., Callejas, S., Thomas, D., Sordet, C., Pohnert, G., Contreras, A., Lafuente, A., Flores-Molina, M., Correa, J. (2012). Seaweeds early development: detrimental effects of desiccation and attenuation by algal extracts. Planta, 235: 337-348.

Cruz, S., Goss, R., Wilhelm, C., Leegood, R., Horton, P., Jakob, T. (2011). Impact of chlororespiration on non-photochemical quenching of chlorophyll fluorescence and on the regulation of the diadinoxanthin cycle in the diatom Thalassiosira pseudonana. Journal of Experimental Botany, 62: 509-519. 
578 Davison IR (1991) Environmental effects on algal photosynthesis: temperature. Journal of Phycology, 27: 2-8.

Davison, I.R., Pearson, G.A. (1996). Stress tolerance in intertidal seaweeds. Journal of Phycology, 32: 197-211.

Davoult, D., Engel, C.R., Arzel, P., Knoch, D., Laurans, M. (2011). Environmental factors and commercial harvesting:exploring possible links behind the decline of the kelp Laminaria digitata in Brittany, France. Cahiers de biologie marine, 52:

tom Dieck (Bartsch), I. (1993). Temperature tolerance and survival in darkness of kelp gametophytes (Laminariales, Phaeophyta): ecological and biogeographical implications. Marine Ecology Progress Series, 100: 253-264.

Edwards, M.S., (2000). The role of alternate life-history stages of a marine macroalga: a seed bank analogue? Ecology 81(9): 2404-2415.

Eilers, P.H.C., Peeters, J.C.H. (1988). A model for the relationship between light intensity and the rate of photosynthesis in phytoplankton. Ecological Modelling, 42: 199-215. 
Fain, S.R., Murray, S.N. (1982). Effects of light and temperature on net photosynthesis and dark respiration of gametophytes and embryonic sporophytes of Macrocystis pyrifera. Journal of Phycology, 18: 92-98.

Falkowski, P.G., Raven, J.A. (1997). Aquatic photosynthesis, Malden, Massachusetts.

Faul, F., Erdfelder, E., Lang, A.-G., Buchner, A. (2007). G*Power 3: A flexible statistical power analysis program for the social, behavorial and biomedical sciences. Behavior Research Methods, 39: 175-191.

Fejtek, S.M., Edwards, M.S., Kim, K.Y. (2011). Elk Kelp, Pelagophycus porra, distribution limited due to susceptibility of microscopic stages to high light. Journal of Experimental Marine Biology and Ecology, 396: 194-201.

Fernández-Marín, B., Míguez, F., Becerril, J.M., García-Plazaola, J. (2011). Activation of violaxanthin cycle in darkness is a common response to different abiotic stresses: a case study in Pelvetia canaliculata. BMC plant biology, 11: 181.

Fredersdorf, J., Müller, R., Becker, S., Wiencke, C., Bischof, K. (2009). Interactive effects of radiation, temperature and salinity on different life history stages of the Arctic kelp Alaria esculenta (Phaeophyceae). Oecologia, 160: 483-492.

Garcia-Mendoza, E., Colombo-Pallotta, M.F. (2007). The giant kelp Macrocystis pyrifera presents a different nonphotochemical quenching control than higher plants. New Phytologist, 173: 526-536.

Genty, B., Briantais, J.M., Baker, N.R. (1989). The relationship between the quantum yield of photosynthetic electron transport and quenching of chlorophyll fluorescence. Biochimica et Biophysica Acta, 990: 87-92. 
Gerard, V.A. (1984). The light environment in a giant kelp forest: influence of Macrocystis pyrifera on spatial and temporal variability. Marine Biology, 84:189-195.

Gerard, V.A. (1988). Ecotypic differentiation in light-related traits of the kelp Laminaria saccharina. Marine Biology, 97: 25-36.

Gevaert, F., Créach, A., Davoult, D., Migné, A., Levavasseur, G., Arzel, P., Holl, A.-C., Lemoine, Y. (2003). Laminaria saccharina photosynthesis measured in situ: photoinhibition and xanthophyll cycle during a tidal cycle. Marine Ecology Progress Series, 247: 43-50.

Han, T., Kain, J.M. (1996). Effect of photon irradiance and photoperiod on young sporophytes of four species of the Laminariales. European Journal of Phycology, 31(3):233-240.

Hanelt, D., Wiencke, C., Karsten, U., Nultsch, W. (1997). Photoinhibition and recovery after high light stress in different developmental and life-history stages of Laminaria saccharina (Phaeophyceae). Journal of Phycology, 33: 387-395.

Harley, C.D.G., Anderson, K.M., Demes, K.W., Jorve, J.P., Kordas, R.L., Coyle, T.A., Graham, M.H. (2012). Effects of climate change on global seaweed communities. Journal of Phycology, 48: 1064-1078.

Havaux, M., Tardy, F. (1996). Temperature-dependent adjustment of the thermal stability of the photosystem II in vivo: possible involvement of xanthophyllcycle pigments. Planta, 198:324-333.

Henkel, S.K., Hofmann, G.E. (2008). Thermal ecophysiology of gametophytes cultured from invasive Undaria pinnatifida (Harvey) Suringar in coastal California harbors. Journal of Experimental Marine Biology and Ecology, 367: 164-173. 
Iizumi, H., Sakanishi, Y. (1994). Temperature dependence of photosynthesis-irradiation (P-I) relationship of gametophytes of Laminaria religiosa Miyabe. Bulletin of Hokkaido National Fisheries Research Institute, 58: 45-51.

Ladah, L.B., Zertruche-Gonzalez, J.A. (2007). Survival of microscopic stages of a perennial kelp (Macrocystis pyrifera) from the centre and the southern extreme of its range in the Northern Hemsiphere after exposure to simulated El Nino stress. Marine Biology, 152: 677 - 686.

Jahns, P., Holzwarth, A.R. (2009). The role of xanthophylls cycle and of lutein in the photoprotection of photosystem II. Biochimica et Biophysica Acta, 1817:182193.

Lavaud, J., Rousseau, B., van Gorkom, H.J., Etienne, A.-L. (2002) Influence of the diadinoxanthin pool size on photoprotection in the marine planktonic diatom Phaeodactylum tricornutum. Plant Physiology, 129(3): 1398-1406.

Ledford, H.K., Niyogi, K.K. (2005). Singlet oxygen and photo-oxidative stress management in plants and algae. Plant, Cell and Environment, 28(8): 10371045.

Lee, J.A., Brinkhuis, B.H. (1988). Seasonal light and temperature interaction effects on development of Laminaria saccharina (Phaeophyta) gametophytes and juveniles sporophytes. Journal of Phycology, 24: 181-191.

Lüning, K. (1990). Seaweeds: their environment, biogeography and ecophysiology, Wiley, New York.

Lüning, K., Neushul, M. (1978). Light and temperature demands for growth and reproduction of laminarian gametophytes in Southern and Central California. Marine Biology, 45: 297-309. 
672 Machalek, K.M., Davison, I.R., Falkowski, P.G. (1996). Thermal acclimation and

673

674

675

676

677

678

679

680

681

682

683

684

685

686

687

688

689

690

691

692

693

694

695 photoacclimation of photosynthesis in the brown alga Laminaria saccharina. Plant, Cell and Environment, 19: 1005-1016.

Mann, K.H. (1973). Seaweeds: their productivity and strategy for growth. The role of large marine algae in coastal productivity is far more important than has been suspected. Science 182, 4116: 975-981.

Martinez, E.A., Santelices, B. (1998). Selective mortality on haploid and diploid microscopic stages of Lessonia nigrescens Bory (Phaeophyta, Laminariales). Journal of Experimental Marine Biology and Ecology, 229: 219-239.

Matson, P.G., Edwards, M.S. (2007). Effects of ocean temperature on the southern range limits of two understory kelps, Pterygophora californica and Eisenia arborea, at multpiple life-stages. Marine Biology 151: 1941-1949.

Mohring, M.B., Kendrik, G.A., Wernberg, T., Rule, M.J., Vanderklift, M.A.(2013). Environmental influences on kelp performance across the reproductive period: an ecological trade-off between gametophyte survival and growth? PLOS ONE 8(6): e65310.

Morris, E.P., Kromkamp, J.C. (2003). Influence of temperature on the relationship between oxygen- and fluorescence-based estimates of photosynthetic parameters in a marine benthic diatom (Cylindrotheca closterium). European Journal of Phycology, 38(2): 133-142.

Oppliger, L.V., Correa, J.A., Engelen, A.H., Tellier, F., Vieira, V., Faugeron, S., Valero, M., Gomez, G., Destombe, C. (2012). Temperature effects on gametophyte life-history traits and geographic distribution of two cryptic kelp species. PLoSOne, 7: e39289. 
Provasoli, L. (1968). Media and prospects for the cultivation of marine algae Cultures and Collections of Algae. Proceedings of the US-Japan Conference, Hakone, September 1966, pp 63-75.

Raven, J.A., Geider, R.J. (2003). Adaptation, acclimation and regulation in algal photosynthesis. In: Larkum, W.D., Douglas, S.E., Raven, J.A. (eds) Photosynthesis in Algae. Kluwer Academic Publishers, Dordrecht, The Netherlands, pp 385-412.

Raybaud, V., Beaugrand, G., Goberville, E., Delebecq, G., Destombe, C., Valero, M., Davoult, D., Morin, P., Gevaert, F., (2013). Decline in kelp in West Europe and climate. PLoSOne 8:e66044.

Reed, D.C., Foster, M.S. (1984). The effects of canopy shading on algal recruitment and growth in a giant kelp forest. Ecology, 65: 937-948.

Roleda, M.Y. (2009). Photosynthetic response of Arctic kelp zoospores exposed to radiation and thermal stress. Photochemical and Photobiological Sciences, 8: 1302-1312.

Roleda, M.Y., Dethleff, D. (2011). Storm-generated sediment deposition on rocky shores: Simulating burial effects on the physiology and morphology of Saccharina latissima sporophytes. Marine Biology Research, 7: 213-223.

Roleda, M.Y., Hanelt, D., Wiencke, C. (2006). Exposure to ultraviolet radiation delays photosynthetic recovery in Arctic kelp zoospres Photosynthesis Research, 88: $311-322$.

Roleda, M.Y., Zacher, K., Wulff, A., Hanelt, D., Wiencke, C. (2008). Susceptibility of spores of different ploidy levels from Antarctic Gigartina skottsbergii (Gigartinales, Rhodophyta) to ultraviolet radiation. Phycologia, 47: 361-370. 
Sauvageau, C. (1915). Sur la sexualite heterogamique d'une Laminaire (Sacchoriza bulbosa). Comptes rendus de l'académie des sciences de Paris, 161: 796-799.

Serôdio, J., Cruz, S., Vieira, S., Brotas, V. (2005). Non-photochemical quenching of chlorophyll fluorescence and operation of the xanthophyll cycle in estuarine microphytobenthos. Journal of Experimental Marine Biology and Ecology, 326: 157-169.

Shapiro, S.S., Wilk, M.B. (1965). An analysis of variance test for normality (complete samples). Biometrika 52, 591-611.

Sharkey, T.D. (2005). Effects of moderate heat stress on photosynthesis: importance of thylakoid reactions, rubisco deactivation, reactive oxygen species, and thermotolerance provided by isoprene. Plant, Cell \& Environment, 28: 269-277.

Staehr, P.A., Wernberg, T. (2009). Physiological responses of Ecklonia radiata (Laminariales) to a latitudinal gradient in ocean temperature. Journal of Phycology, 45: 91-99.

Sukenik A, Bennett J, Falkowski PG (1987) Light-saturated photosynthesis - limitation of electron transport or carbon fixation? Biochimica et Biophysica Acta, 891: 205-215.

Takahashi, S., Murata, N. (2008). How do environmental stresses accelerate photoinhibition? Trends in Plant Science, 13: 178-182.

Walters, R.G. (2005). Towards an understanding of photosynthetic acclimation. Jounal of Experimental Botany, 56: 435-447.

Wang, C., Fan, X., Wang, G., Niu, J., Zhou, B. (2011). Differential expression of rubisco in sporophytes and gametophytes of some marine macroalgae. PLoSOne, 6: e16351. 
Wernberg, T., Russell, B.D., Moore, P.J., Ling, S.D., Smale, D.A., Campbell, A., Coleman, M.A., Steinberg, P.D., Kendrick, G.A., Connell, S.D. (2011a). Impact of climate change in a global hotspot for temperate marine biodiversity and ocean warming. Journal of Experimental Marine Biology and Ecology 400: 716.

Wernberg, T., Russell, B.D., Thomsen, M.S., Gurgel, F.D., Bradshaw, C.J.A, Poloczanska, E.S., Connell, S.D. (2011b). Seaweed communities in retreat from ocean warming. Current Biology 21: 1828-1832.

Wernberg, T., Smale, D.A., Thomsen, M.S. (2012). A decade of climate change experiments on marine organisms: procedures, patterns and problems. Global Change Biology, 18: 1491-1498.

Wernberg, T., Smale, D.A., Tuya, F., Thomsen, M.S., Langlois, T.J., de Bettignies, T., Bennett, S., Rousseaux, C.S. (2013). An extreme climatic event alters marine ecosystem structure in a global biodiversity hotspot. Nature Climate Change, $3: 78-82$. 
761 Fig. 1 Photosynthesis-irradiance curves ( $P$ - $I$ curves) of gametophytes in L. digitata from

762 Wissant $(\square)$ and $\operatorname{Roscoff}(\bullet)(\mathrm{n}=3)$, expressed as $(\mathbf{A})$ relative electron transport rate

$763\left(r E T R, \mu \mathrm{mol} \mathrm{e}^{-} \mathrm{m}^{-2} \mathrm{~s}^{-1}\right),(\mathbf{B})$ gross oxygen production on a fresh weight basis (GP, $\mu \mathrm{mol}$

$\left.764 \mathrm{O}_{2} \mathrm{~g}_{\mathrm{FW}}{ }^{-1} \mathrm{~h}^{-1}\right)$ and $(\mathbf{C})$ gross oxygen production per unit chl $a\left(\mathrm{GP}, \mu \mathrm{mol} \mathrm{O} \mathrm{O}_{2}\right.$ nmoles chl $a$ $\left.765{ }^{1} h^{-1}\right)$.

766 Fig. $2 N P Q$ of gametophytes in L. digitata from Wissant $(\square)$ and $\operatorname{Roscoff}(\bullet)(n=3)$

767 measured during the data collection for the rETR-I curves.

768 Fig. 3 (A) Relative optimal quantum yield (rel. $\left.F_{v} / F_{m}\right)$ and $(\mathbf{B})$ de-epoxidation ratio of 769 violaxanthin into antheraxanthin and zeaxanthin of gametophytes in L. digitata from 770 Wissant $(\square)$ and Roscoff $(\bullet)(\mathrm{n}=3)$. Gametophytes were first exposed to high irradiance $\left(500 \mu \mathrm{mol}\right.$ photons $\left.\mathrm{m}^{-2} \mathrm{~s}^{-1}\right)$ for $2 \mathrm{~h}$ and then to dim white light $(10 \mu \mathrm{mol}$ 772 photons $\left.\mathrm{m}^{-2} \mathrm{~s}^{-1}\right)$.

773 Fig. 4 Photosynthetic parameters $\left(\alpha(\mathrm{A}), r E T R_{\max }(\mathrm{B})\right.$ and $\left.I_{k}(\mathrm{C})\right)$ and maximal $N P Q$ $774\left(N P Q_{250}\right)(\mathrm{D})$ of gametophytes in L. digitata from Wissant $(\square)$ and $\operatorname{Roscoff}(\square)(\mathrm{n}=3)$. 775 Gametophytes acclimated at $5^{\circ} \mathrm{C}, 10^{\circ} \mathrm{C}, 15^{\circ} \mathrm{C}$ and $20^{\circ} \mathrm{C}$ exposed to increasing 776 irradiance at the temperature of acclimation. Photosynthetic parameters $\left(\alpha, r E T R_{\max }\right.$ and $777 I_{k}$ ) were calculated using the model of Eilers \& Peeters (1988).

778 Fig. 5 Relative optimal quantum yield (rel. $F_{v} / F_{m}$ ) of gametophytes in L. digitata from Wissant $(\square)$ and Roscoff $(\bullet)(\mathrm{n}=3)$. Gametophytes initially kept at $10^{\circ} \mathrm{C}$ were 
781 intervals). Data were fitted using a non-linear regression analysis $\left(y=a^{*} e^{\left(b^{*} \times / c\right)}+d\right)$. 
784 Table 1 Environmental conditions in the two sites at the time of collection and 1 month

785 prior to sampling. Environmental data were provided by T. Carriou from the Station

786 Biologique de Roscoff and the Somlit network.

\begin{tabular}{|c|c|c|c|c|}
\hline & \multicolumn{2}{|c|}{ Roscoff } & \multicolumn{2}{|c|}{ Wissant } \\
\hline & Time of collection & 1 month prior & Time of collection & 1 month prior \\
\hline Daylenght (hh:mm) & 09:13 & 10:51 & 09:30 & 08:50 \\
\hline $\begin{array}{l}\text { Daily surface irradiance } \\
\left(\mathrm{mol} \text { photons. } \mathrm{m}^{-2} \cdot \mathrm{j}^{-1}\right)\end{array}$ & 4.13 & 11.12 & 5.45 & 8.04 \\
\hline $\begin{array}{l}\text { Light attenuation of PAR } \\
\left(m^{-1}\right)\end{array}$ & 0.21 & $0.20 \pm 0.01$ & 0.34 & $0.37 \pm 0.06$ \\
\hline $\begin{array}{l}\text { Sea Surface Temperature } \\
\left({ }^{\circ} \mathrm{C}\right)\end{array}$ & 12.8 & $13.4 \pm 0.8$ & 5.1 & $5.3 \pm 0.4$ \\
\hline Salinity & 35.2 & $35.2 \pm 0.0$ & 34.5 & $34.5 \pm 0.1$ \\
\hline Dissolved $\mathrm{NO}_{3}\left(\mu \mathrm{mol} . \mathrm{L}^{-1}\right)$ & 8.00 & $6.83 \pm 1.07$ & 13.62 & $13.42 \pm 0.34$ \\
\hline Dissolved $\mathrm{PO}_{4}\left(\mu \mathrm{mol} . \mathrm{L}^{-1}\right)$ & 0.49 & $0.45 \pm 0.05$ & 0.40 & $0.46 \pm 0.07$ \\
\hline
\end{tabular}

787 
790 Table 2 Pigment composition (moles per 100 moles of all pigments) and pigment ratios

791 (x 100) of gametophytes in L. digitata from Roscoff and Wissant $(\mathrm{n}=3)$. Significant

792 results $($ Holm-adjusted $P<0.05)$ are highlighted in bold.

Holm-

$1-\beta$

adjusted $P$

\section{Pigment concentrations}

Chlorophyll $a(\operatorname{chl} a)$

Chlorophyll $c(\operatorname{chl} c)$

Fucoxanthin

Violaxanthin $(\mathrm{Vx})$

$\beta$ carotene

Pigment ratios

Antenna:chl $a$ pigment ratio

$\Sigma \mathrm{XC}: \operatorname{chl} a$ pigment ratio

$\Sigma X C$ :antenna pigment ratio
$54.51 \pm 2.64$

$8.15 \pm 0.65$

$30.41 \pm 3.00$

$2.11 \pm 0.49$

$0.61 \pm 0.37$

$77.13 \pm 9.11$

$5.52 \pm 1.53$

$7.17 \pm 2.01$
$50.05 \pm 2.93$

$3.10 \pm 1.75$

$37.85 \pm 3.81$

$3.54 \pm 0.31$

$0.69 \pm 0.33$

$89.65 \pm 10.56$

$9.28 \pm 1.88$

$10.28 \pm 0.89$
1.96

4.69

2.66

4.26

0.27

1.55

2.68

2.45
0.243

0.33

0.047

0.169

0.047

0.802

0.06

793 
795 Table 3 Results of multivariate PERMANOVA analysis to test for differences in

796 temperature and sites. Data were normalised and dissimilarities calculated as Euclidian

797 distances. $P$-values were calculated from 999 permutations of the residuals under the

798 reduced model. Significant results $(P<0.05)$ are highlighted in bold.

799

\begin{tabular}{|c|c|c|c|c|c|}
\hline & & df & Mean squares & Pseudo-F & $P($ perm $)$ \\
\hline \multirow[t]{4}{*}{$\alpha$} & Site & 1 & 0.0052 & 1.5444 & 0.237 \\
\hline & Temperature & 3 & 0.0307 & 9.0127 & 0.009 \\
\hline & Site $x$ Temperature & 1 & 0.0001 & 0.0058 & 0.928 \\
\hline & Residual & 20 & 0.0034 & & \\
\hline \multirow[t]{4}{*}{$I_{k}$} & Site & 1 & 745.0 & 2.742 & 0.100 \\
\hline & Temperature & 3 & 20189.3 & 76.516 & 0.001 \\
\hline & Site $\mathbf{x}$ Temperature & 1 & 423.8 & 1.560 & 0.211 \\
\hline & Residual & 20 & 271.7 & & \\
\hline \multirow[t]{4}{*}{$\boldsymbol{r E T R}_{\max }$} & Site & 1 & 15.35 & 0.717 & 0.417 \\
\hline & Temperature & 3 & 1122.24 & 52.420 & 0.001 \\
\hline & Site $x$ Temperature & 1 & 22.51 & 1.051 & 0.321 \\
\hline & Residual & 20 & 21.41 & & \\
\hline \multirow[t]{4}{*}{$N P Q_{\max }$} & Site & 1 & 11.2083 & 11.21 & 0.001 \\
\hline & Temperature & 3 & 12.0839 & 12.08 & 0.001 \\
\hline & Site $x$ Temperature & 1 & 0.0335 & 0.03 & 0.080 \\
\hline & Residual & 20 & 0.5527 & 0.55 & \\
\hline
\end{tabular}

800 

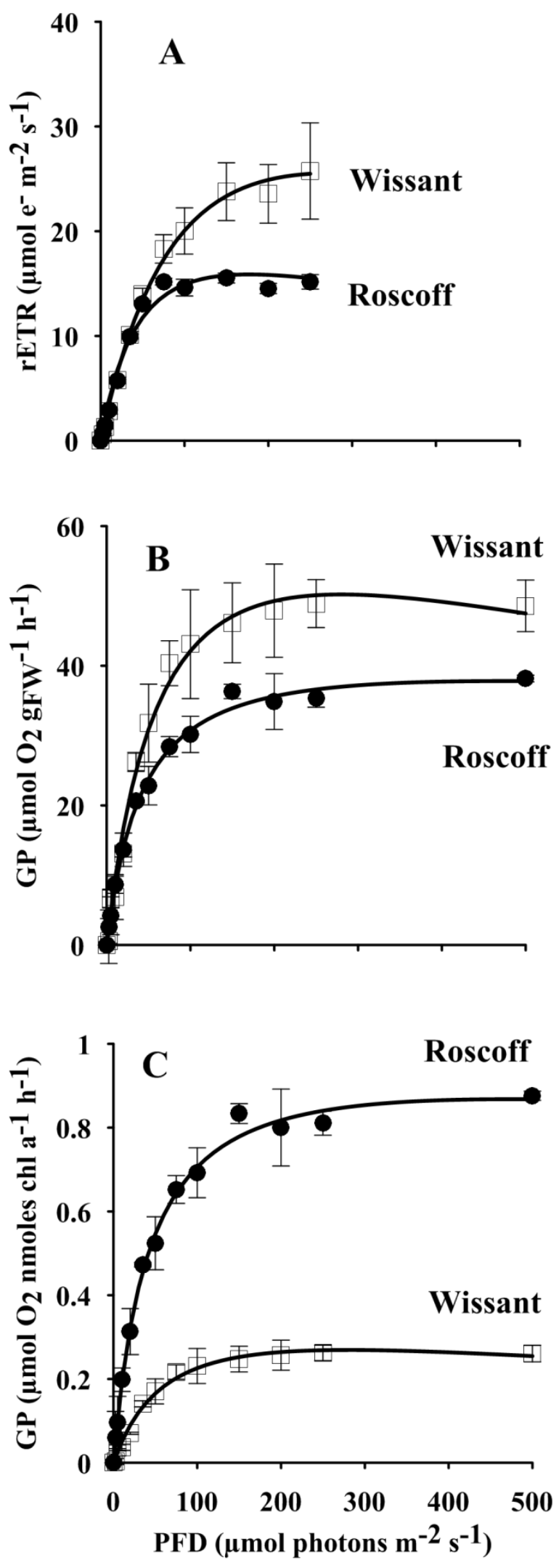

Fig. 1 


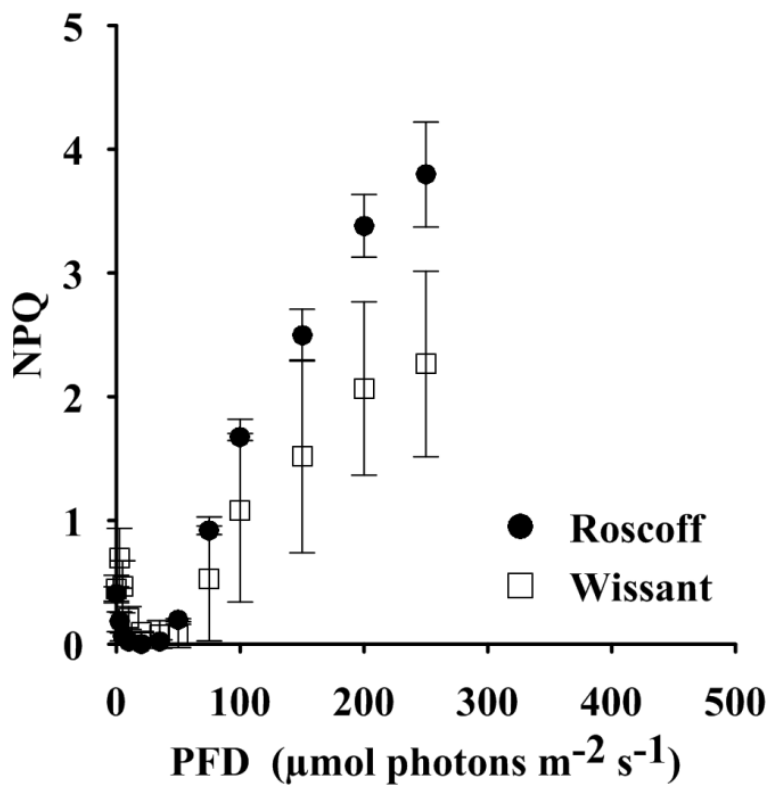

804

Fig. 2

805 


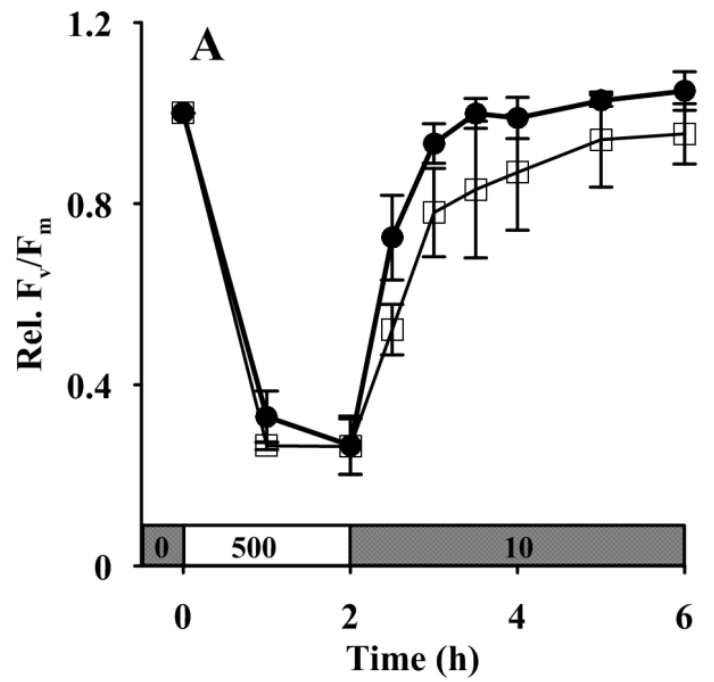

806

807

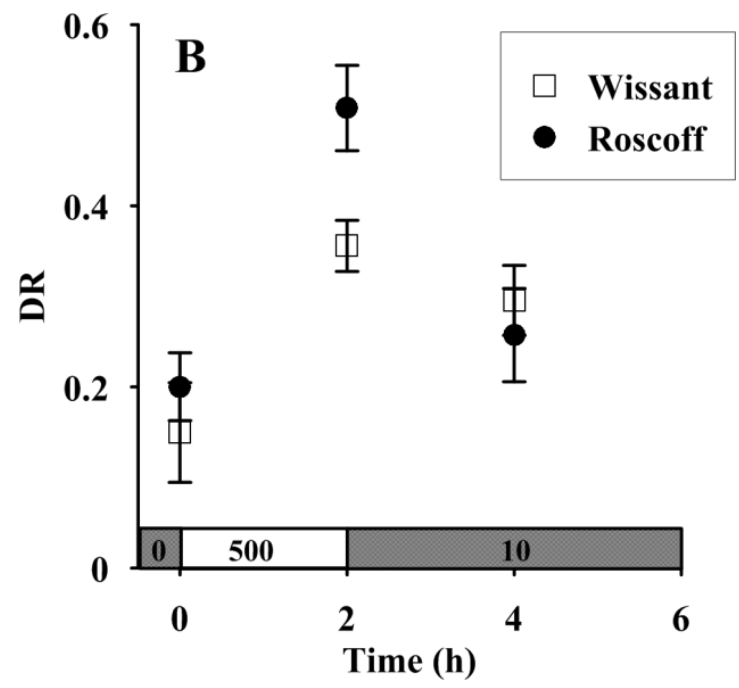

Fig. 3 

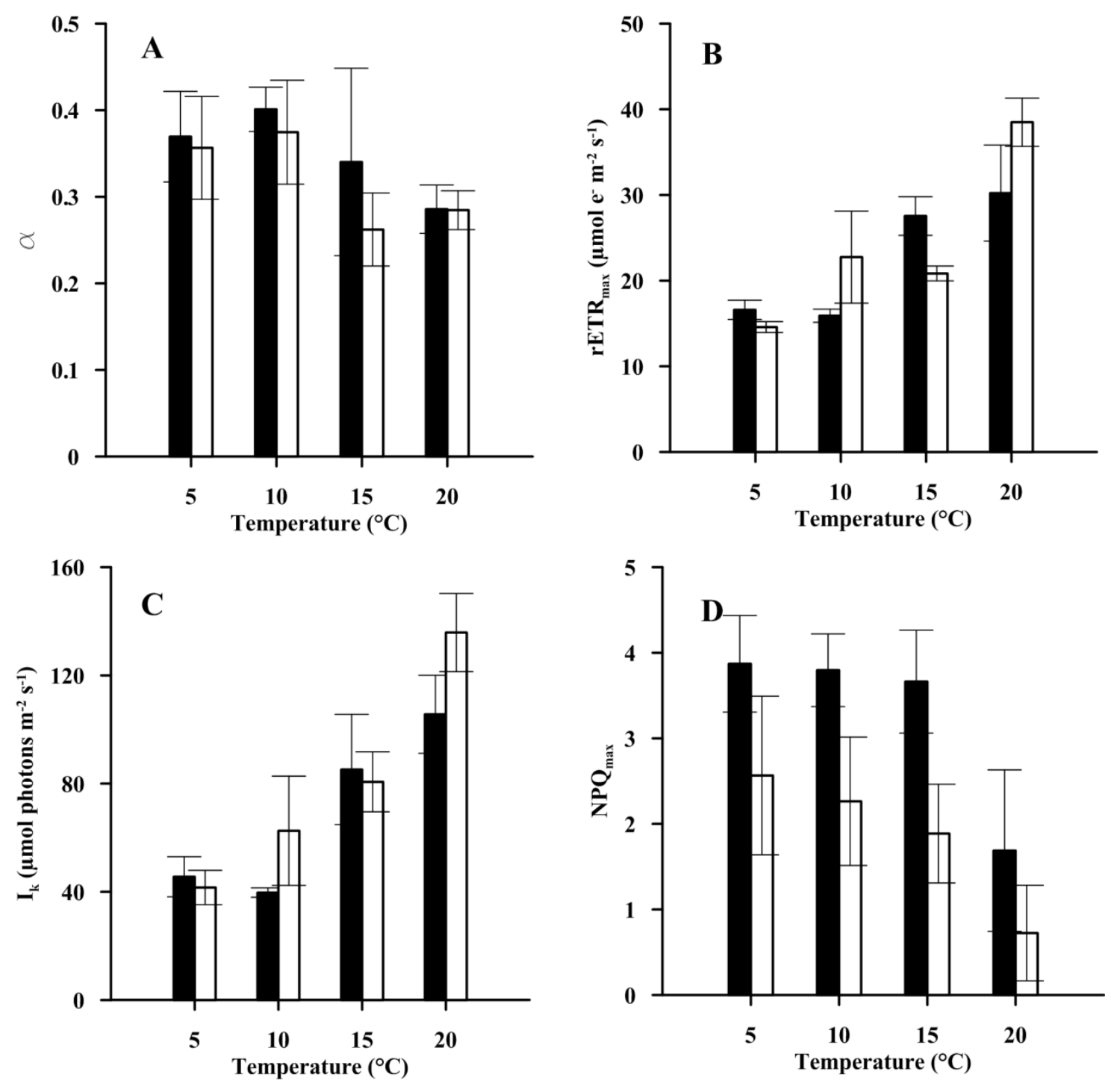

Fig. 4 


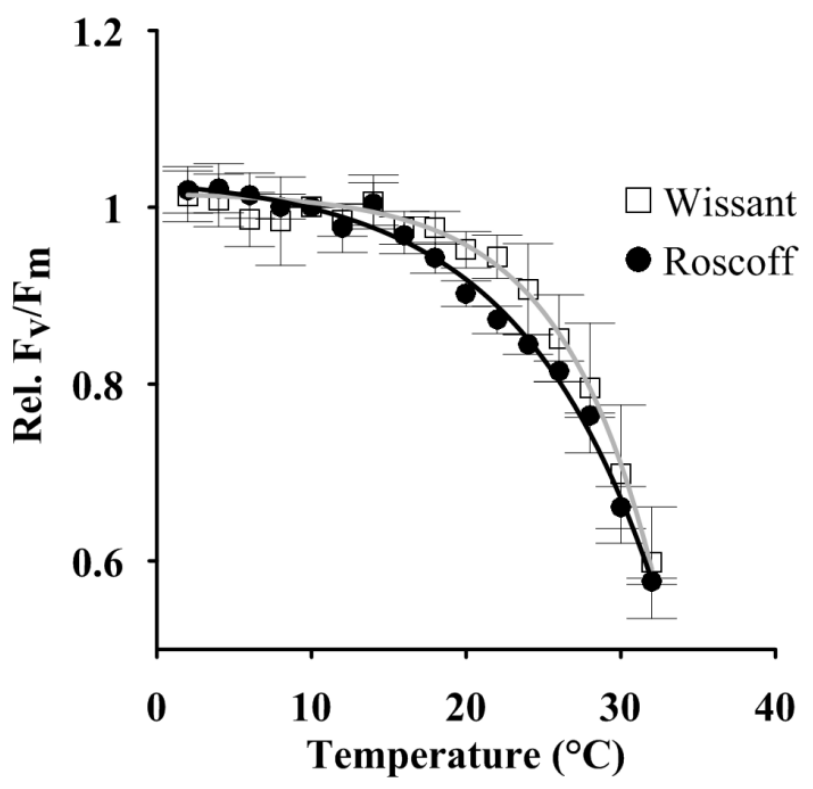

Fig. 5 